\title{
Korelasi otitis media dengan temuan nasoendoskopi pada penderita rinosinusitis akut
}

\author{
Ariel Anugrahani, Teti Madiadipoera, Arif Dermawan \\ Departemen Telinga Hidung Tenggorok - Bedah Kepala Leher \\ Fakultas Kedokteran Universitas Padjajaran/Rumah Sakit Dr. Hasan Sadikin \\ Bandung
}

\begin{abstract}
ABSTRAK
Latar belakang: Rinosinusitis akut adalah inflamasi pada hidung dan sinus paranasal yang berlangsung kurang dari 12 minggu. Adanya sumbatan pada hidung dapat menyebabkan sumbatan pada tuba Eustachius sehingga dapat terjadi gangguan ventilasi dan inflamasi yang dapat menimbulkan otitis media. Tujuan: Melihat adanya hubungan hidung tersumbat, nasal edema, dan rinore pada pasien rinosinusitis akut dengan otitis media. Metode: Penelitian dengan desain cross sectional study dan data diambil secara deskriptif retrospektif dari rekam medis, di Poliklinik Rinologi Alergi Ilmu Kesehatan THT-KL RSHS Bandung, dalam periode Januari 2013 - Juni 2014. Didapatkan jumlah sampel sebanyak 93 pasien yang terdiri dari 38 pasien dengan OMA, 27 pasien dengan OME, dan 28 pasien dengan OMSK, dengan usia 1 sampai 79 tahun, berdasarkan derajat berat penyakit menurut Visual Analogue Scale (VAS), gejala hidung berdasarkan Weeke, Davis dan Okuda, pemeriksaan nasoendoskopi berdasarkan Lund-Kennedy. Analisis data menggunakan uji Kruskal-Wallis, chi square $(\mathrm{p}<0,05)$, dan analisis korelasi Spearman. Hasil: Terdapat korelasi yang bermakna antara otitis media dengan temuan nasoendoskopi yaitu edema mukosa dan rinore. Kesimpulan: Terdapat hubungan antara peningkatan gejala obstruksi hidung dan edema mukosa serta rinore pada temuan nasoendoskopi pada penderita rinosinusitis akut dengan otitis media.
\end{abstract}

Kata kunci: rinosinusitis akut, nasoendoskopi, otitis media

\begin{abstract}
Background: Acute rhinosinusitis is an inflammation of the nose and paranasal sinuses, which going on less than 12 weeks. If the Eustachian tube obstruction occurs, there will be ventilation and inflammatory disorders that can cause otitis media. Purpose: This study aimed to find out the correlation of nasal obstruction, nasal edema, and rhinorrhea in acute rhinosinusitis patients with otitis media. Methods: The study was a cross sectional study which data were collected from retrospective descriptive study based on medical record at Rhinology-Allergy Clinic of ORL-HNS Department, Dr. Hasan Sadikin General Hospital, Bandung, from January 2013 to June 2014, involved 93 patients from 1 to 79 years old. Data were analyzed by using the Kruskal-Wallis, chi square, and Spearman statistical test based on anamnesis, severity of the disease using Visual Analogue Scale, nasal symptoms from Weeke, Davis and Okuda, nasoendoscopy findings from Lund-Kennedy. Results: There was a significant correlation between otitis media with mucosal edema and rhinorrhea from nasoendoscopy. Conclusion: There was a correlation between the increased symptoms of nasal obstruction,mucosal edema, and rhinorrhea in nasoendoscopy findings in patients with acute rhinosinusitis with the occurrence of otitis media.
\end{abstract}

Key words: acute rhinosinusitis, nasoendoscopy, otitis media

Korespondensi: Ariel Anugrahani, Departemen THT-KL UNPAD/RSHS. Jl. Pasteur 38, Bandung. Email :dr.arielanugrahani@gmail.com 


\section{PENDAHULUAN}

Rinosinusitis merupakan inflamasi pada mukosa hidung dan sinus paranasal, ditandai dengan dua atau lebih gejala, dengan salah satu gejala harus mencakup hidung tersumbat, adanya sekret hidung, diikuti nyeri wajah atau gangguan penghidu. Pada pemeriksaan nasoendoskopi didapatkan adanya sekret mukopurulen yang berasal dari meatus medius dan atau edema/obstruksi mukosa primer pada meatus medius, pada pemeriksaan Tomografi Komputer (TK) didapatkan perubahan mukosa pada kompleks osteomeatal dan atau sinus paranasal. Rinosinusitis dikategorikan akut apabila gejala yang timbul kurang dari 12 minggu dan mengalami resolusi komplit. ${ }^{1}$

Di Indonesia, angka kejadian rinosinusitis akut masih belum pasti. Data yang terdapat di Kementerian Kesehatan Republik Indonesia 2010, menyebutkan bahwa pada tahun 2009 penyakit infeksi saluran nafas atas menduduki peringkat pertama dalam 10 besar data penyakit pada pasien rawat jalan. ${ }^{2}$ Data dari subbagian Rinologi Ilmu Kesehatan Telinga Hidung dan Tenggorok Bedah Kepala dan Leher (THT-KL) Rumah Sakit Umum Pusat Nasional (RSUPN) Dr. Cipto Mangunkusumo menunjukkan angka kejadian rinosinusitis yang tinggi yaitu $69 \%$ dari 435 pasien rawat jalan yang datang selama periode JanuariAgustus 2005. ${ }^{3}$ Data di subbagian RinologiAlergi Ilmu Kesehatan Telinga Hidung dan Tenggorok Bedah Kepala dan Leher (THTKL) Rumah Sakit Hasan Sadikin (RSHS) pada tahun 2010 angka kejadian rinosinusitis sebesar 44\% dan pada tahun 2012 didapatkan angka kunjungan pasien dengan rinosinusitis akut sebesar $17,89 \%{ }^{4}$

Rinosinusitis akut dipicu oleh penyumbatan ostium sinus, dimana fisiologi sinus normalnya tergantung pada patensi dari ostium sinus maupun mekanisme drainase mukosiliar. Terhambatnya drainase mukosiliar akan menyebabkan penumpukan lendir di rongga sinus. Pemahaman sebelumnya bahwa rinosinusitis akut terutama disebabkan oleh infeksi bakteri telah ditentang oleh penelitian terbaru yang lebih menekankan pada mekanisme respon inflamasi. Selain faktor infeksi, tingginya prevalensi rinosinusitis akut di antaranya juga dipengaruhi oleh kelembaban lingkungan, polusi udara, dan juga variasi struktur anatomi sinus paranasal. Sekarang ini banyak bukti yang mengarah pada hipotesis mengenai inflamasi alergi secara terus-menerus dan paparan asap rokok terhadap timbulnya rinosinusitis akut melalui perubahan motilitas dan fungsi silia. ${ }^{1,5,6}$ Diagnosis rinosinusitis akut terutama dengan melihat pemeriksaan klinis. Lebih dari $50 \%$ pasien dengan gejala rinosinusitis yang mengunjungi perawatan primer dokter, kemungkinan tidak disebabkan oleh bakteri.

Otitis media (OM) adalah peradangan pada sebagian atau seluruh mukosa telinga tengah, tuba Eustachius, antrum mastoid, dan sel-sel mastoid. Patogenesis otitis media berhubungan erat dengan tuba Eustachius. Fungsi tuba Eustachius adalah sebagai ventilasi atau pengatur keseimbangan antara tekanan udara di dalam telinga tengah dan tekanan udara luar, pelindung terhadap sekret nasofaring ke telinga tengah, dan saluran sekret telinga tengah ke nasofaring. Bila terjadi sumbatan tuba Eustachius, maka akan terjadi gangguan ventilasi. Tekanan udara di dalam telinga tengah menjadi negatif karena udara akan diabsorbsi oleh mukosa telinga tengah. Akibatnya, cairan dari pembuluh darah kapiler dapat tertarik keluar memasuki telinga tengah dan menyebabkan akumulasi cairan di telinga tengah. Cairan ini merupakan media yang baik untuk pertumbuhan bakteri ${ }^{5,7,8-11}$

Keluhan dan gejala awal yang dirasakan penderita gangguan fungsi tuba Eustachius antara lain nyeri telinga, berdengung, rasa penuh di telinga hingga vertigo. Hal tersebut menyebabkan rasa tidak nyaman dan dapat memengaruhi kualitas hidup penderita. Jika terjadi gangguan fungsi tuba, maka dapat berlanjut menjadi otitis media akut (OMA), otitis media efusi (OME) dan otitis 
media supuratif kronis (OMSK), atelektasis membran timpani, dan retraction pocket. ${ }^{6}$ Temuan terbaru beberapa studi pada anak-anak dengan dan tanpa otitis media menunjukkan kurangnya kemampuan tuba Eusthacius untuk menyamakan tekanan telinga tengah dan udara luar. Gangguan fungsi tuba ditemukan pada anak-anak penderita otitis media efusi sebanyak $71,8 \%$ dan $51,8 \%$ pada dewasa. ${ }^{8-10}$

Tujuan penelitian adalah untuk melihat adanya hubungan hidung tersumbat, nasal edema, dan rinore dari temuan nasoendoskopi pada pasien rinosinusitis akut yang mengalami otitis media (OMA, OME, OMSK tipe aman aktif dengan eksaserbasi akut atau persistensi otore yang berhubungan dengan rinosinusitis akut rekuren).

\section{METODE}

Penelitian dilakukan di poliklinik Rinologi Alergi THT-KL RSHS/FKUP, periode Januari 2013 - Juni 2014. Subjek penelitian adalah semua pasien yang datang berobat ke poliklinik THT-KL RSHS dengan pilek atau hidung tersumbat kurang dari 12 minggu. Sampel adalah pasien yang telah terdiagnosis sebagai pasien rinosinusitis akut disertai adanya otitis media akut (OMA), otitis media efusi (OME) dan otitis media supuratif kronis (OMSK) dengan usia 1 sampai 79 tahun.

Penelitian menggunakan desain cross sectional. Jenis data adalah deskriptif retrospektif yang diambil dari rekam medis. Subjek penelitian adalah pasien yang didiagnosis rinosinusitis akut dengan hasil positif pada alat diagnostik THT dan endoskopi rigid.

Penelitian dilakukan pada 93 pasien rinosinusitis akut yang bersamaan menderita OMA, OME, OMSK tipe aman aktif (38 pasien dengan OMA, 27 pasien dengan OME, dan 28 pasien OMSK). Penilaian derajat berat dari gejala rinosinusitis akut berdasarkan keluhan subjektif yang diderita pasien menurut EP3OS berupa rinore, hidung tersumbat, nyeri/rasa tertekan di wajah dan gangguan penghidu. Penggunaan Visual Analogue Scale (VAS) terbukti relevan secara klinis dalam mengukur derajat berat tiap-tiap gejala subjektif yang dirasakan pasien. Pasien diminta menilai berat atau ringannya keluhan berdasarkan gambar dan dianalogikan ke dalam skala 0 (tidak ada keluhan) sampai skala 10 (keluhan sangat berat) dan dikelompokkan menjadi 3 kelompok yaitu ringan (skala 0-3), sedang (skala 4-7), dan berat (skala >7). ${ }^{1,12}$ Pada penelitian ini, gejala telinga tidak dikuantifikasi secara spesifik dikarenakan subjek penelitian sudah dikelompokkan sesuai dengan diagnosis OMA, OME, dan OMSK yang pada saat itu sedang menderita rinosinusitis akut.

Penilaian berdasarkan skor nasoendoskopi, dinilai ada tidaknya edema mukosa dan sekret hidung berdasarkan kriteria Lund dan Kennedy. Skor sekret terdiri dari skor 0 (tidak didapatkan sekret hidung), skor 1 (sekret encer dan bening), dan skor 2 (sekret purulen dan kental). Skor edema mukosa terdiri dari skor 0 (tidak didapatkan edema mukosa), skor 1 (edema mukosa ringan), dan skor 2 (edema mukosa berat). ${ }^{6}$

\section{HASIL}

Selama Januari 2013 - Juni 2014, dilakukan penelitian terhadap 93 pasien dengan rinosinusitis akut dari usia 1 sampai 79 tahun didapatkan 38 pasien dengan disertai dengan OMA (40,8\%), 27 pasien dengan OME $(29,03 \%)$, dan 28 pasien dengan OMSK $(30,17 \%)$.

Tabel 1 menunjukkan bahwa lakilaki lebih banyak menderita otitis media dibandingkan dengan perempuan. Sedangkan dari usia 1 sampai 79 tahun didapatkan lebih banyak pasien dengan usia muda menderita rinosinusitis akut yang mengalami otitis media. Hal ini menunjukkan hasil yang bermakna menurut uji Kruskal Wallis. 
Tabel 1. Karakteristik subjek pada ketiga kelompok penelitian

\begin{tabular}{|c|c|c|c|c|}
\hline \multirow[b]{2}{*}{ Karakteristik } & \multicolumn{3}{|c|}{ Kelompok otitis media } & \multirow[b]{2}{*}{ Nilai p* } \\
\hline & $\begin{array}{l}\text { OMA } \\
(n=38)\end{array}$ & $\begin{array}{l}\text { OME } \\
(n=27)\end{array}$ & $\begin{array}{l}\text { OMSK } \\
(n=28)\end{array}$ & \\
\hline Jenis kelamin & & & & 0,515 \\
\hline Laki-laki & $20(52,6 \%)$ & $18(66,7 \%)$ & $17(60,7 \%)$ & \\
\hline Perempuan & $18(47,4 \%)$ & $9(33,3 \%)$ & $11(39,3 \%)$ & \\
\hline Usia (tahun) & & & & $<0,001$ \\
\hline Median & 10,5 & 22 & 33 & \\
\hline Rentang & $2-62$ & $1-62$ & $10-79$ & \\
\hline
\end{tabular}

*) nilai p untuk jenis kelamin berdasarkan uji chi square dan nilai p untuk usia berdasarkan uji Kruskal Wallis

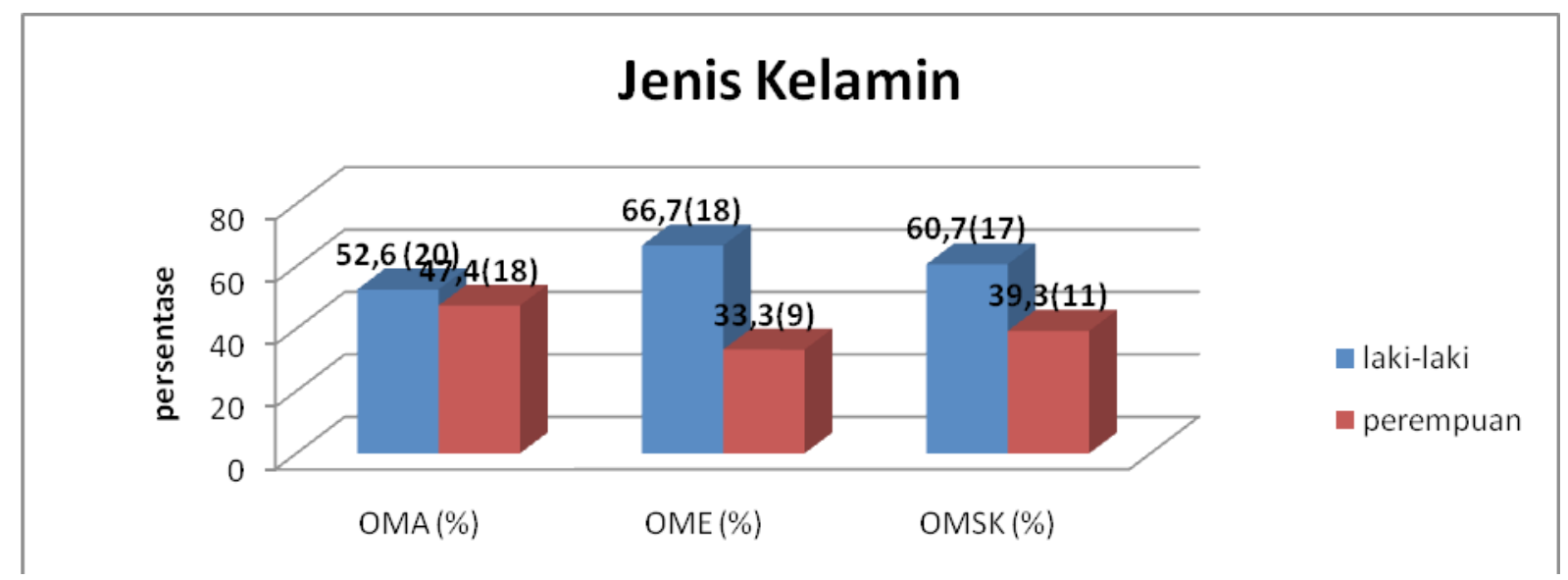

Gambar 1. Distribusi penderita rinosinusitis akut dengan otitis media berdasarkan jenis kelamin

Tabel 2 menunjukkan, berdasarkan skala gangguan subjektif rinosinusitis akut menurut visual analogue scale, keluhan pasien terbanyak untuk gejala rinore yaitu derajat sedang sebanyak 19 orang (50\%) pada OMA, derajat sedang sebanyak 18 orang $(66,7 \%)$ pada OME, derajat sedang pada OMSK sebanyak 14 orang $(50 \%)$. Keluhan hidung tersumbat yaitu derajat sedang sebanyak 21 orang (84\%), keluhan rasa sakit/tertekan di wajah yaitu derajat ringan sebanyak 21 orang (84\%), sedangkan keluhan hidung penurunan penciuman yaitu derajat ringan sebanyak 21 orang $(84 \%)$. Menurut uji chi square didapatkan hasil yang kurang bermakna.
Dari tabel 3 didapatkan temuan pemeriksaan dari nasoendoskopi rigid pada pasien rinosinusitis akut yang mengalami otitis media didapatkan hasil adanya edema mukosa dengan skala ukur berat pada pasien otitis media akut sebanyak 25 orang dan pada otitis media efusi sebanyak 17 pasien. Sedangkan pada otitis media supuratif kronis didapatkan nasal edema dengan skala ukur derajat sedang. Berdasarkan uji chi square didapatkan korelasi bermakna $(\mathrm{p}<0,005)$ antara edema mukosa dan dengan timbulnya otitis media serta korelasi yang tidak bermakna dengan uji chi square $(\mathrm{p}=0,083)$ antara rinorea dengan dengan otitis media. 
Tabel 2. Gambaran visual analogue scale terhadap otitis media

\begin{tabular}{|c|c|c|c|c|c|}
\hline \multirow[b]{2}{*}{ VAS } & \multirow[b]{2}{*}{ Skala ukur } & \multicolumn{3}{|c|}{ Otitis media } & \multirow[b]{2}{*}{ Nilai $p$} \\
\hline & & $\begin{array}{c}\text { OMA } \\
(n=38)\end{array}$ & $\begin{array}{c}\text { OME } \\
(n=27) \\
\end{array}$ & $\begin{array}{c}\text { OMSK } \\
(n=28)\end{array}$ & \\
\hline \multirow[t]{3}{*}{ Rinore } & Ringan & $15(39,5 \%)$ & $7(25,9 \%)$ & $12(42,9 \%)$ & \\
\hline & Sedang & $19(50 \%)$ & $18(66,7 \%)$ & $14(50 \%)$ & 0,649 \\
\hline & Berat & $4(10,5 \%)$ & $2(7,4 \%)$ & $2(7,1 \%)$ & \\
\hline \multirow[t]{3}{*}{ Hidung tersumbat } & Ringan & $6(15,8 \%)$ & $5(18,5 \%)$ & $9(32,1 \%)$ & \\
\hline & Sedang & $30(78,9 \%)$ & $19(70,4 \%)$ & $14(50 \%)$ & 0,160 \\
\hline & Berat & $2(5,3 \%)$ & $3(11,1 \%)$ & $5(17,9 \%)$ & \\
\hline \multirow[t]{3}{*}{ Nyeri wajah } & Ringan & $18(47,4 \%)$ & $22(81,5 \%)$ & $15(53,6 \%)$ & \\
\hline & Sedang & $12(31,6 \%)$ & $3(11,1 \%)$ & $10(35,7 \%)$ & 0,053 \\
\hline & Berat & $8(21,1 \%)$ & $2(7,4 \%)$ & $3(10,7 \%)$ & \\
\hline \multirow[t]{3}{*}{ Penurunan penciuman } & Ringan & $20(68,4 \%)$ & $16(59,3 \%)$ & $15(53,6 \%)$ & \\
\hline & Sedang & $11(28,9 \%)$ & $10(37 \%)$ & $12(42,9 \%)$ & 0,812 \\
\hline & Berat & $1(2,6 \%)$ & $1(3,7 \%)$ & $1(3,6 \%)$ & \\
\hline
\end{tabular}

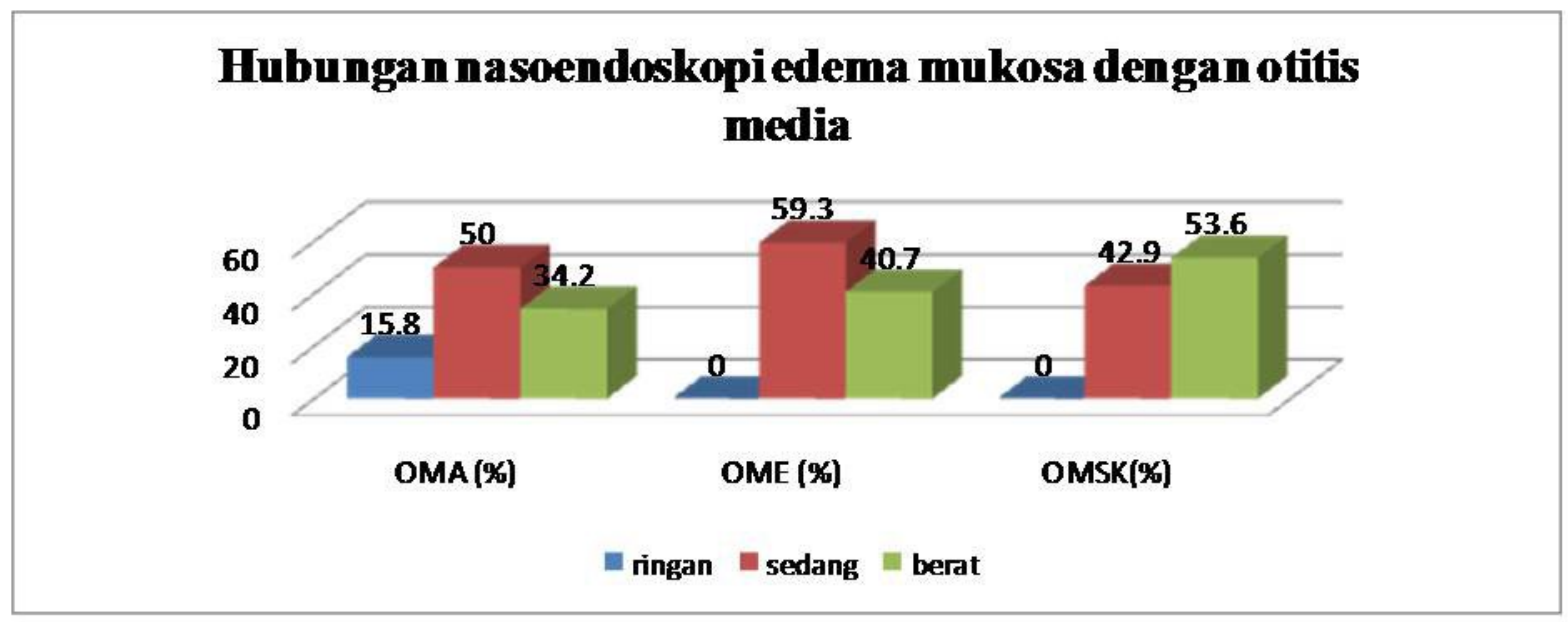

Gambar 2. Hubungan temuan nasoendoskopi edema mukosa dengan otitis media

Tabel 3. Hubungan temuan nasoendoskopi terhadap otitis media

\begin{tabular}{|c|c|c|c|c|c|}
\hline \multirow[b]{2}{*}{ Nasoendoskopi } & \multirow[b]{2}{*}{ Skala ukur } & \multicolumn{3}{|c|}{ Otitis media } & \multirow[b]{2}{*}{ Nilai p* } \\
\hline & & $\begin{array}{c}\text { OMA } \\
(n=38)\end{array}$ & $\begin{array}{c}\text { OME } \\
(n=27)\end{array}$ & $\begin{array}{c}\text { OMSK } \\
(n=28)\end{array}$ & \\
\hline \multirow[t]{3}{*}{ Edema mukosa } & Ringan & 3 & 0 & 0 & \\
\hline & Sedang & 10 & 10 & 18 & 0,006 \\
\hline & Berat & 25 & 17 & 7 & \\
\hline \multirow[t]{3}{*}{ Rinorea } & Ringan & 6 & 0 & 1 & \\
\hline & Sedang & 19 & 16 & 12 & 0,083 \\
\hline & Berat & 13 & 11 & 15 & \\
\hline
\end{tabular}

*) Berdasarkan Uji t 
Tabel 4. Gambaran hasil gangguan pendengaran pada pasien dengan rinosinusitis akut dengan otitis media

\begin{tabular}{lccc}
\hline Hasil audiogram & $\begin{array}{c}\text { OMA } \\
(\mathrm{n}=38)\end{array}$ & $\begin{array}{c}\text { OME } \\
(\mathrm{n}=27)\end{array}$ & $\begin{array}{c}\text { OMSK } \\
(\mathrm{n}=28)\end{array}$ \\
\hline Normal & 5 & 0 & 0 \\
Tuli konduktif ringan & 27 & 7 & 3 \\
Tuli konduktif sedang & 5 & 5 & 17 \\
Tuli konduktif berat & 1 & 10 & 5 \\
Tuli konduktif sangat berat & 0 & 2 & 0 \\
Sensorineural ringan & 0 & 2 & 1 \\
Sensorineural sedang & 0 & 1 & 2 \\
\end{tabular}

Dari hasil pemeriksaan audiometri didapatkan hubungan yang bermakna $(\mathrm{p}<0,001)$ tentang adanya hubungan tuli konduktif pada pasien rinosinusitis akut yang mengalami otitis media. Dari tabel 5 didapatkan adanya korelasi yang signifikan antara edema mukosa, rinore, dan hasil audiometri berdasarkan perhitungan koefisien korelasi Spearman dengan nilai $p<0,05$. Tanda negatif menunjukkan semakin ke arah OMA, keluhan semakin berat, sedangkan tanda positif menunjukkan bahwa semakin ke arah OMSK, gejala semakin berat.

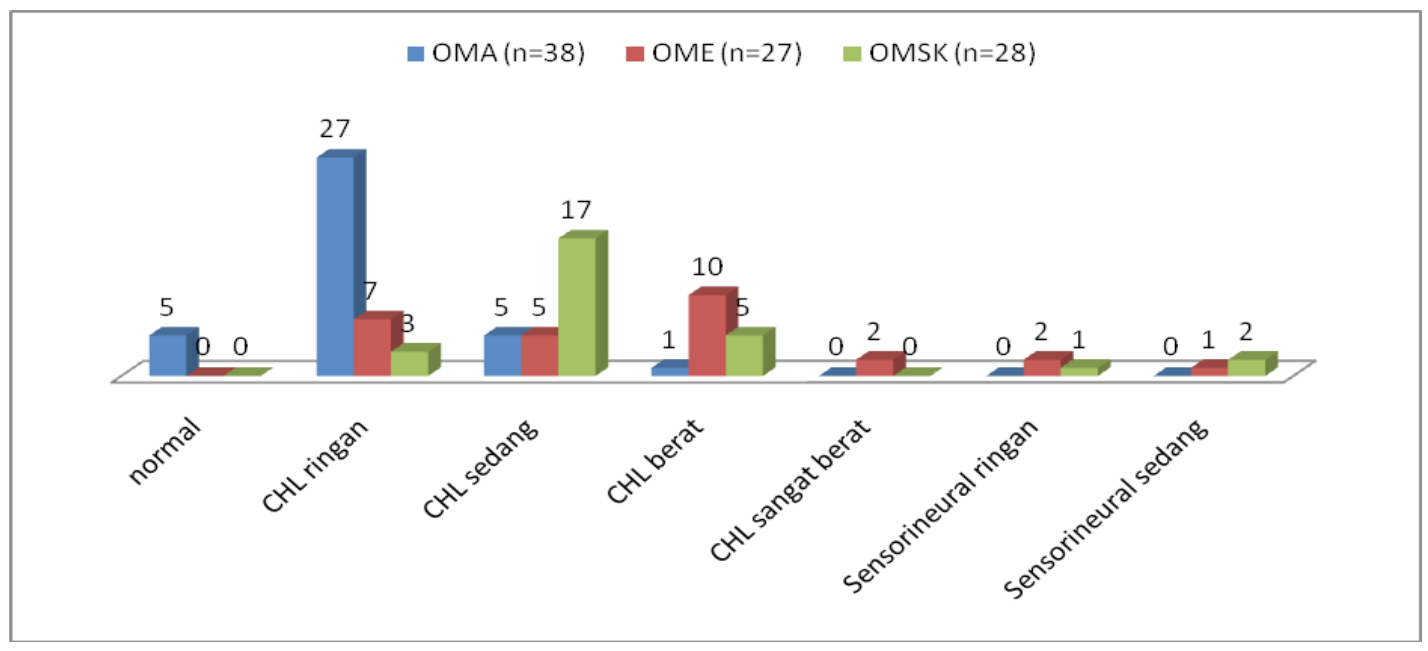

Gambar 3. Gambaran hasil gangguan pendengaran pada pasien rinosinusitis akut dengan otitis media

Tabel 5. Korelasi antara berbagai pengukuran dengan komplikasi $(n=93)$

\begin{tabular}{lrr}
\hline Korelasi komplikasi & Rs & $\mathbf{p}$ \\
\hline Edema mukosa & $-0,299$ & 0,004 \\
Rinore & 0,205 & 0,0048 \\
Audiometri & 0,606 & $<0,001$ \\
VAS nyeri wajah & $-0,113$ & 0,281 \\
VAS penurunan penciuman & 0,127 & 0,224 \\
VAS rinore & $-0,028$ & 0,789 \\
VAS hidung tersumbat & $-0,036$ & 0,733 \\
\hline
\end{tabular}

Rs : koefisien korelasi Spearman bermakna jika $\mathrm{p}<0,05$ 


\section{DISKUSI}

Distribusi subjek penelitian,pasien rinosinusitis akut berdasarkan jenis kelamin, terdiri dari 55 orang laki-laki (20 pasien dengan OMA, 18 pasien dengan OME, 17 pasien dengan OMSK) dan 38 perempuan (18 pasien dengan OMA, 9 pasien dengan OME, dan 11 pasien dengan OMSK). Walaupun penyebabnya tidak diketahui, namun hal tersebut berkebalikan dengan yang diungkapkan pada EPO3S dimana prevalensi rinosinusitis akut ditemukan lebih tinggi pada wanita dibandingkan pria dengan rasio 6:4. ${ }^{1}$ Penelitian lain di Kanada memperlihatkan rentang prevalensi sekitar 3,4\% pada pria dan $5,7 \%$ pada wanita. Pada penelitian ini, pasien rinosinusitis akut yang mengalami otitis media lebih banyak terjadi pada laki-laki dibandingkan pada wanita.

Jumlah pasien rinosinusitis yang berobat ke poliklinik subbagian Rinologi THT-KL FK Unpad/RSHS dari Januari 2013 - Juni 2014 ditemukan sebanyak 812 pasien yang terdiri dari penderita rinosinusitis akut dan rinosinusitis kronik. Sebanyak 93 dari 812 pasien rinosinusitis akut menderita otitis media. Akan tetapi, penelitian ini belum dapat menggambarkan prevalensi yang sebenarnya karena sedikitnya jumlah sampel.

Pasien rinosinusitis akut yang mengalami otitis media di RSHS adalah pada rentang usia 1-79 tahun, dengan usia terbanyak 10-33 tahun. Kepustakaan lain mengatakan bahwa angka kejadian otitis media biasanya terjadi pada usia yang lebih muda terutama pada anak-anak usia 3-6 tahun dengan prevalensi terbanyak pada usia 6-36 bulan yang dapat disebabkan oleh virus atau bakteri. Lokasi primer patologi otitis media berada pada tuba Eustachius yang mengalami disfungsi tuba. Penyebaran infeksi biasanya berasal dari nasofaring ke telinga tengah yang mengalami tahapan oklusi tuba menjadi pre supurasi lalu menjadi supurasi dan kemudian mengalami resolusi atau komplikasi. ${ }^{8,9}$ Beberapa penelitian melaporkan mekanisme gangguan fungsi tuba Eustachius rinosinusitis akut didasari oleh kesamaan antara mukosa rongga hidung, nasofaring, tuba Eustachius, dan telinga tengah, sehingga proses inflamasi alergi di mukosa hidung dapat berlanjut ke mukosa nasofaring dan tuba Eustachius. Gangguan fungsi tuba merupakan salah satu faktor penyebab otitis media yang memiliki peranan penting dalam patogenesis terjadinya otitis media efusi. Gangguan fungsi tuba ditemukan $71,7 \%$ pada kelompok pasien dengan otitis media kronis dan hanya didapatkan $34,9 \%$ yang normal. Otitis media efusi merupakan salah satu penyakit yang paling sering diderita anak-anak dan dan banyak menghabiskan biaya pengobatan. Pengobatan otitis media efusi di Amerika Serikat menghabiskan biaya lebih dari 4 milyar dolar dan di Inggris Raya sebanyak 27,8 juta dolar. ${ }^{13,14}$

Dalam sebuah studi di Brazil, sebanyak 51 pasien berusia 3-55 tahun dengan OME menjalani perawatan bedah otologi, kemudian dievaluasi untuk adanya rinitis alergi atau rinitis non-alergi dengan sindrom eosinofil (NARES=non allergic rhinitis eosinophilic syndrome). Rinitis alergi dan NARES didiagnosis pada 33,3\% dan 15,7\% pasien dengan otitis media kronis. Mereka menyimpulkan ada hubungan antara rinitis alergi dan OME. Beberapa penelitian lain yang telah dilakukan menunjukan adanya hubungan rinosinusitis akut (OMA) dan otitis media efusi (OME), tetapi dilaporkan bahwa kejadian otitis media efusi lebih sering terjadi disebabkan adanya rinitis alergi. ${ }^{14,15}$

Pada penelitian ini, gejala yang dinilai meliputi hidung tersumbat, hidung beringus, nyeri wajah, penurunan penciuman, dan total skor gejala hidung. Dari hasil penelitian dengan uji statistik chi square, didapatkan hasil yang tidak bermakna dimana nilai $\mathrm{p}>0,05$. Tetapi, jika menggunakan uji linear dengan Spearman didapatkan hasil yang positif pada hidung tersumbat yang menunjukkan hubungan yang bermakna untuk terjadinya 
otitis media. Hal ini juga didapatkan pada penelitian dari Adoga dkk, ${ }^{14}$ yaitu sebanyak 141 pasien yang mengalami infeksi saluran napas bagian atas yang mengalami otitis media, didapatkan gejala hidung terbanyak adalah hidung tersumbat $(\mathrm{n}=37)$ dan rinorea $(\mathrm{n}=37)$. Keluhan lainnya berupa batuk $(\mathrm{n}=17)$, penurunan pendengaran $(\mathrm{n}=26)$, otalgia $(\mathrm{n}=18)$, dan tinitus $(\mathrm{n}=8)$.

Pada penelitian ini didapatkan penderita OMSK dengan rinosinusitis akut sebanyak 28 orang $(30,17 \%)$. Terjadinya OMA menjadi awal penyebab OMSK yang merupakan suatu invasi mukoperiosteum organisme virulen, terutama berasal dari nasofaring yang terdapat paling banyak pada masa anak-anak. Selama fase aktif, epitel mukosa mengalami perubahan menjadi mukosa sekretorik dengan sel goblet yang mengekskresi sekret yang mukopurulen atau mukoid. Adanya sekret persisten yang berlangsung lama akan menyebabkan mukosa mengalami proses pembentukan jaringan granulasi dan/atau polip yang menutupi membran timpani sehingga mengganggu sistem drainase. ${ }^{16}$ Pada OMSK tipe aman aktif dengan tuba Eustachius sering tersumbat oleh edema, apakah merupakan fenomena primer atau sekunder yang masih belum diketahui secara pasti. Faktor yang menyebabkan perforasi membran timpani menetap pada OMSK antara lain infeksi yang menetap pada telinga tengah yang mengakibatkan produksi sekret telinga purulen berlanjut, adanya obstruksi tuba Eustachius yang berkelanjutan, dan tidak terjadinya penutupan spontan karena terhambatnya mekanisme migrasi epitel skuamous. Sedangkan faktor yang menyebabkan penyakit infeksi telinga tengah supuratif menjadi kronik bisa majemuk antara lain adanya gangguan fungsi tuba Eustachius yang kronis atau berulang dikarenakan adanya infeksi di hidung dan tenggorok yang kronis atau berulang, perforasi membran timpani yang menetap, terjadinya metaplasia skuamosa atau perubahan patologis menetap lainnya pada telinga tengah, obstruksi menetap terhadap aerasi telinga atau rongga mastoid (jaringan parut, penebalan mukosa, polip, jaringan granulasi, atau timpanosklerosis), terdapat daerah-daerah dengan sekuester atau osteomielitis persisten di mastoid, dan faktor konstitusi dasar seperti alergi atau kelemahan dari sistem pertahanan tubuh. ${ }^{17}$

Skor nasoendoskopi digunakan untuk menilai ada tidaknya edema mukosa dan sekret hidung berdasarkan kriteria Lund dan Kennedy. Hasil dari penelitian ini adalah didapatkan hasil yang bermakna dimana didapatkan hasil $\mathrm{p}<0,05$ dari uji chi square dan koefisien korelasi Spearman. Hasil penelitian ini dapat dijadikan suatu pedoman untuk melihat adanya hubungan rinosinusitis akut dengan otitis media.

Dari hasil pemeriksaan audiometri didapatkan hubungan yang bermakna $(p<0,001)$ tentang adanya hubungan tuli konduktif pada pasien rinosinusitis akut yang mengalami otitis media. Pemeriksaan audiometri pada OME didapatkan hasil tuli konduktif, dimana hantaran udara mengalami penurunan di bawah batas normal dengan adanya gap pada hantaran tulang dan udara Gangguan pendengaran (tuli konduktif) merupakan konsekuensi akibat terjadinya otitis media. Semua pasien OM pasti akan mengalami gangguan konduksi. Namun, perlu dilakukan penelitian lebih lanjut dengan pemeriksaan audiometri pada penderita rinosinusitis akut yang tidak mengalami $\mathrm{OM}$ untuk melihat apakah terdapat gangguan pendengaran. Pada penelitian ini juga tidak dilakukan anamnesis adanya rinitis alergi dan uji cukit kulit pada saat pemeriksaan. Hal ini dapat dijadikan sebagai saran untuk penelitian selanjutnya untuk melihat hubungan gejala telinga dengan komorbid rinitis alergi dan peran rinitis alergi pada rinosinusitis akut.

Nemati $\mathrm{dkk}^{18}$ dalam penelitiannya di Iran mengemukakan bahwa OMSK merupakan penyakit inflamasi persisten yang multifaktorial pada telinga tengah. Mekanisme patofisiologi yang berbeda, yang menghubungkan rinitis alergi dan OMSK tetap 
berkembang. Dari hasil penelitian didapatkan prevalensi yang tinggi dari rinitis kronik (alergi dan non alergi) yaitu ditemukan gejala rinore anterior, obstruksi atau kongesti nasal, bersin, terutama hidung gatal paroksismal, post nasal drip, pembengkakan pada konka secara signifikan pada pasien OMSK, dan prevalensi dari rinitis alergi telah dibuktikan dengan adanya hasil yang positif dari tes cungkit kulit.

Disimpulkan bahwa terdapat korelasi yang bermakna dari hasil temuan nasoendoskopi pada pasien rinosinusitis akut yaitu adanya nasal edema dan rinorea yang berhubungan dengan terjadinya sumbatan pada tuba Eustachius dan terjadinya otitis media.

\section{DAFTAR PUSTAKA}

1. Fokkens WJ, Lund VJ, Mullol J, Bachert C, Alobid C, Baroody F, et al. EPOS 2012: European position paper on rhinosinusitis and nasal polyps 2012. A summary for otorhinolaryngologists. Rhinology. 2012; 50(1):1-12.

2. Rosita R, Soepardi J. Profil Kesehatan Indonesia 2009. Jakarta: Kementrian Kesehatan RI, 2010; 33.

3. Soetjipto D, Mangunkusumo E. Sinus Paranasal dan Sinusitis, Dalam :Buku Ajar Ilmu Kesehatan Telinga Hidung Tenggorokan Kepala \& Leher. Edisi Keenam. Jakarta : Balai Penerbit FK UI ; 2009.

4. Burhanuddin A. Kadar IL-8 sekret hidung sebagai indikator efektifitas terapi klaritromisin pada rhinosinusitis kronik disertai alergi. Tesis. Bandung : Bagian THT-KL FK UNPAD-RSHS dan Program Pendidikan Magister ; 2011

5. Hartanto WW, Madiadipoera T. Otitis media sebagai komorbid rinitis alergi di bagian THT-KL RSHS Bandung periode 1 Januari - 31 Desember 2008. Disampaikan pada Pertemuan Ilmiah Tahunan Otology 4, Palembang, 2009.
6. Lund VJ, Kennedy DW. Staging for rhinosinusitis. Otolaryngol Head Neck Surg. 1997; 117(3 Pt 2):S35-40.

7. Krouse HJ, Derebery MJ, Chadwick SJ. Otitis media: background and science. In managing in allegic patient, ed $1^{\text {st }}$. USA: Elsevier. 2008:175-190.

8. Leibovitz E. Acute otitis media in pediatric medicine: current issues in epidemiology, diagnosis, and management. Peadiatr Drugs. 2003;5(suppl 1):1-12.

9. Ilechukwu GC, Ilechukwu CGA, Ubesie AC, Ojinnaka CN, Emechebe GO, Iloh KK. Otitis Media in Children: Review Article. Open Journal of Pediatrics. 2014; 4:47-53.

10. Dhingra, PL. Eustachian tube and its disorder. Diseases of ear, nose, and throat. Fourth Edition. Elsevier. 2007. India. 56-60.

11. Azimi G, Amiri S, Divanbeigi A. Eusthacian tube function in repeated upper respiratory tract infections. Australian journal of basic and applied sciences. 2011; 5(11):943-945.

12. Ciprandi G, Mora F, Cassano M, Gallina AM, Mora R. Visual analog scale (VAS) and nasal obstruction in persistent allergic rhinitis. Otolaryngol Head Neck Surg. 2009; 141(4):527-9.

13. Straetemans M, Heerbeek N, Schilder AG, Feuth T, Rijkers GT, Zielhuis GA. Eustachian tube function before recurrence of otitis media with effusion. Arch Otolaryngol Head Neck Surg. 2005; 131(2): 118- 123.

14. Adoga AA, Nimkur TL. Acute otitis media complicating upper respiratory tract infection : knowledge and treatment outcomes in health professionals. Journal of Medicine in the Tropics. 2013; 15(2):135-9.

15. Al Anazy FH. The role of nasal allergy in otitis media with effusion. Bahrain Medical Bulletin. 2011; 33(1):1-5.

16. Kenna MA, Larz AD. Otitis media and middle ear effusion, In Bailey BJ, Johnson JT, Newlands SD, Editors. Head and Neck Surgery-Otolaryngology. $4^{\text {th }}$ ed. Philadelphia, USA. Lippincott Williams \& Wilkins. 2006; $1: 1265-75$ 
17. Nursiah S. Pola kuman aerob penyebab OMSK dan kepekaan terhadap beberapa antibiotika di bagian THT FK USU/RSUP H. Adam Malik Medan. Tesis. Medan: Pascasarjana Universitas Sumatera Utara; 2003.
18. Nemati S, Ebrahim N, Kazemnejad E, Aghajanpour M, Abdollahi O. Middle ear exploration results in suspected otosclerosis cases: are ossicular and footplate area anomalies rare? Iranian Journal of Otorhinolaryngology. 2015; 25(72):155160. 